\title{
Fe-Nb-Zn (Iron-Niobium-Zinc)
}

\section{Raghavan}

Recently, [2009Tu] determined an isothermal section for this ternary system at $450{ }^{\circ} \mathrm{C}$.

\section{Binary Systems}

The Fe-Nb phase diagram has the following intermediate phases: $\mathrm{Fe}_{2} \mathrm{Nb}\left(C 14, \mathrm{MgZn}_{2}\right.$-type hexagonal) and $\mathrm{Fe}_{7} \mathrm{Nb}_{6}$ $\left(D 8_{5}, \mathrm{Fe}_{7} \mathrm{~W}_{6}\right.$-type rhombohedral; denoted $\left.\mu\right)$. In the $\mathrm{Fe}-\mathrm{Zn}$ system, the intermediate phases are: $\Gamma\left(\mathrm{Fe}_{3} \mathrm{Zn}_{10} ; \mathrm{Cu}_{5} \mathrm{Zn}_{8^{-}}\right.$ type cubic), $\Gamma_{1}\left(\mathrm{Fe}_{11} \mathrm{Zn}_{40}\right.$; cubic), $\delta$ (FeZn ${ }_{10}$-type hexagonal) and $\zeta\left(\mathrm{CoZn}_{13}\right.$-type monoclinic). The following intermediate phases form by peritectic reactions in the $\mathrm{Nb}-\mathrm{Zn}$ system [1992Mos]: $\mathrm{NbZn}, \mathrm{NbZn}_{1.5}$ (hexagonal), $\mathrm{NbZn}_{2}\left(C 36, \mathrm{MgNi}_{2}\right.$-type hexagonal), $\mathrm{NbZn}_{3}\left(L_{2}, \mathrm{AuCu}_{3}-\right.$ type cubic), $\mathrm{NbZn}_{7}$, and $\mathrm{NbZn}_{15}$. The stability of a reported phase at $\mathrm{Nb}_{3} \mathrm{Zn}$ is not known [1992Mos].

\section{Ternary Isothermal Section}

With starting metals of $99.99 \%$ purity, [2009Tu] prepared 8 equilibrated alloys and $\mathrm{Fe}-\mathrm{Nb} / \mathrm{Zn}$ diffusion couples. The time of equilibration was 60 days at $450{ }^{\circ} \mathrm{C}$ and the diffusion anneal was 30 days at the same temperature, followed water quenching. The phase equilibria were studied with scanning electron microscope equipped with wavelength-dispersive and energy-dispersive $x$-ray spectroscopy and x-ray powder diffraction. The measured compositions of the co-existing phases were listed. The isothermal section at $450{ }^{\circ} \mathrm{C}$ constructed by [2009Tu] is shown in Fig. 1. The ternary phase T, which is isostructural with the binary $\Gamma_{1}$, has a homogeneity range. The binary Fe-Zn compounds $\delta, \Gamma_{1}$ and $\Gamma$ dissolve $0.1,0.4$ and 1.0 mass $\% \mathrm{Nb}$ respectively. $\mathrm{Fe}_{2} \mathrm{Nb}$ dissolves up to 6.2 at. $\% \mathrm{Zn}$.

\section{References}

1992Mos: Z. Moser, The Nb-Zn (Niobium-Zinc) System, J. Phase Equilib., 1992, 13(4), p 425-429

2009Tu: H. Tu, X. Su, F. Yin, X. Wang, and J. Wang, $450{ }^{\circ} \mathrm{C}$ Isothermal Section of the $\mathrm{Zn}-\mathrm{Fe}-\mathrm{Nb}$ Ternary System at the Zn-Rich Corner, J. Alloys Compd., 2009, 485, p 270-274

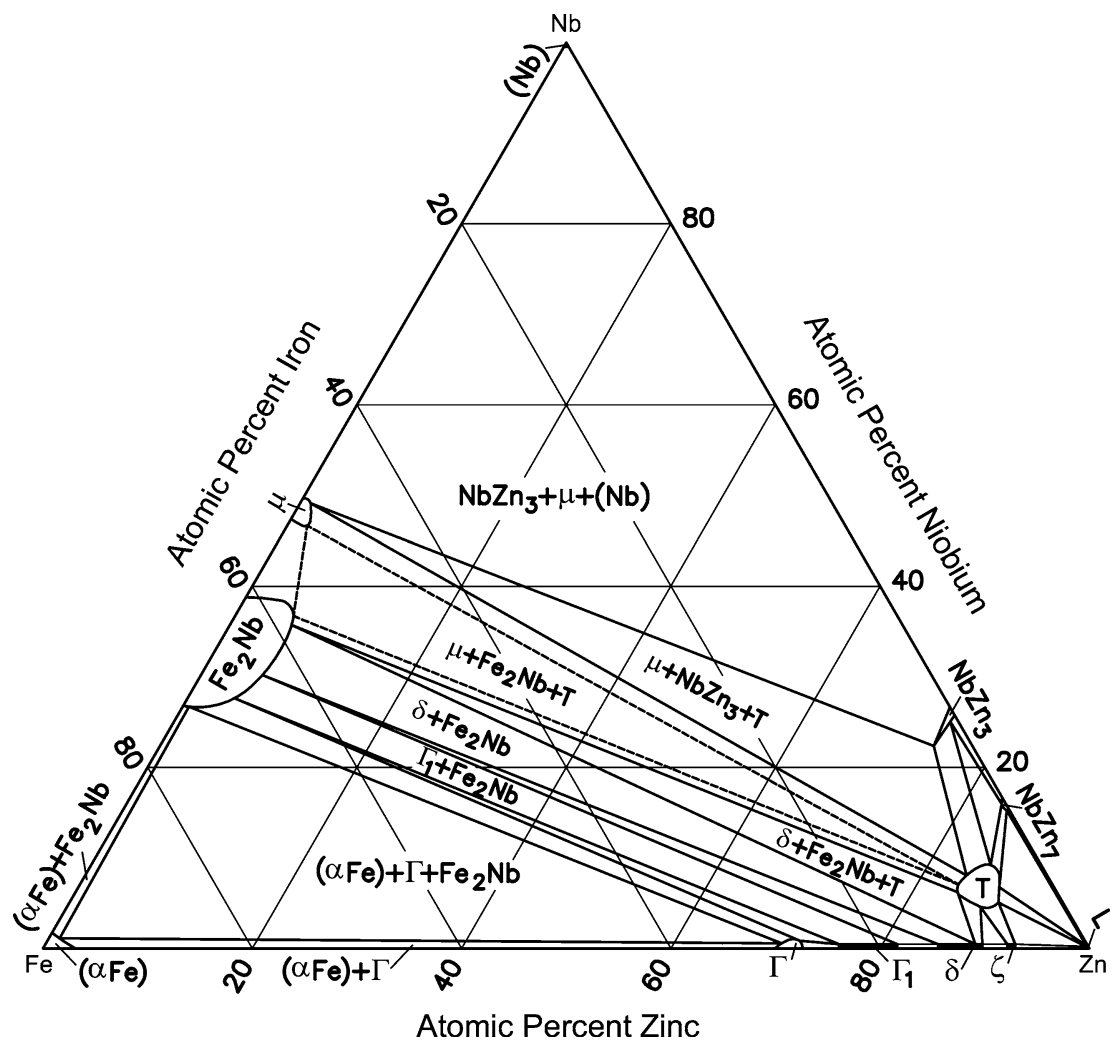

Fig. 1 Fe-Nb-Zn isothermal section at $450{ }^{\circ} \mathrm{C}$ [2009Tu] 